\author{
Asian Journal of \\ Medical and Biological Research \\ ISSN 2411-4472 (Print) 2412-5571 (Online) \\ www.ebupress.com/journal/ajmbr
}

\title{
Article \\ Effect of different level of molasses inclusion on feed intake, body weight gain and carcass parameters of Afar sheep in Ethiopia
}

\author{
Anwar Seid Hassen ${ }^{1}$ and Mohammed Yasin $\mathrm{Ali}^{2}$ \\ ${ }^{1}$ Afar Pastoral and Agro Pastoral Research Institute, Department of Livestock Research Directorate, P.O. Box \\ 16, Samara, Ethiopia \\ ${ }^{2}$ Dubti Pastoral Agro Pastoral Research Center, Department of Livestock Research Core Process, Dubti, \\ Ethiopia
}

*Corresponding author: Anwar Seid Hassen, Afar Pastoral and Agro Pastoral Research Institute, Department of Livestock Research Directorate, P.O. Box 16, Samara, Ethiopia. Phone: + 25109 11562968; E-mail: anu751751751@gmail.com

Received: 26 January 2019/Accepted: 22 February 2019/ Published: 31 March 2019

\begin{abstract}
The experiment was conducted to evaluate the effect of supplementing different levels of molasses and concentrates mix with a basal diet of cultivated pasture hay on intake, body weight and carcass quality of Afar sheep. Twenty four yearling Afar sheep, grouped in to four groups of six animals each in a randomized complete block design. The experiment consisted of four months feeding trial each group will receive the experimental feeds. Treatments were mixed concentrate $+20 \%$ inclusion molasses $\left(\mathrm{T}_{1}\right)$, mixed concentrate + $15 \%$ inclusion molasses $\left(\mathrm{T}_{2}\right)$, mixed concentrate $+10 \%$ inclusion molasses $\left(\mathrm{T}_{3}\right)$ and $0 \%$ inclusion $\left(\mathrm{T}_{4}\right)$. In this experiment with mean initial weight of $15.9 \pm 0.39 \mathrm{~kg}$ (mean $\pm \mathrm{SD}$ ), $16.2 \pm 0.41 \mathrm{~kg}, 16.3 \pm 0.42 \mathrm{k} . \mathrm{g}$ and $16.1 \mathrm{~kg} \pm 0.42$ respectively, were used in each treatment group. The experiment was consisted of 90 days of feeding trial followed by carcass evaluation. The concentrate mix were 2:1 (wheat bran and cotton seed cake) The CP content of the panicum antidotale hay, concentrate mix and molasses were $95 \mathrm{~g} / \mathrm{kg} \mathrm{DM}, 252 \mathrm{~g} / \mathrm{kg} \mathrm{DM}$, and $38.4 \mathrm{~g} / \mathrm{kg}$, respectively. Hay DM intake was did not differ $(\mathrm{P}<0.05)$ among all treatments. Average daily weight gain $(A D G)$ was higher $(\mathrm{P}<0.05)$ for $\mathrm{T}_{2}(69.59 \mathrm{~g} / \mathrm{kg})$ compared to other treatments. Hot carcass weight also higher $(\mathrm{P}<0.05)$ for $\mathrm{T}_{2}(14.41 \mathrm{~kg})$. Weight gains $12.31 \mathrm{~kg}, 13.83 \mathrm{~kg}, 11.25 \mathrm{~kg}$ and $10.26 \mathrm{~kg}$ for $\mathrm{Tx}_{1}, \mathrm{Tx}_{2}, \mathrm{Tx}_{3}$ and $\mathrm{Tx}_{4}$, respectively). All Carcass parameters gave advantage $(\mathrm{P}<0.01)$ to $\mathrm{Tx} 2$. From the present study, it can be concluded that $\mathrm{Tx}_{2}$ sheep performed better than $\mathrm{Tx}_{1}, \mathrm{Tx}_{3}$, and $\mathrm{Tx}_{4}$ in terms of body weight gain, Feed intake, and carcass parameters.
\end{abstract}

Keywords: molasses; panicum grass; Afar sheep; slaughter weight; hot carcass; concentrate mix

\section{Introduction}

The Afar region is predominating by pastoral communities whose livelihood is entirely dependent on livestock herding. The livestock sector is also dependent on the natural pasture of the range lands. However, almost all of the available range lands of the region are characterized as over grazed. Therefore low quality and inadequacy of feeds as well as malnutrition are considered to be the major constraints hampering productivity of livestock in the region. Feed and water scarcity in quality and quantity especially during the long dry season are among noted production constraints of the livestock sector (Getachew et al., 2005). Feed production covers requirements only in exceptional good years; the deficit reaching $35 \%$ in normal years and $70 \%$ in bad years (FAO, 2004). To minimize the impact of fluctuations in seasonal feed availability, supplementation of concentrates is known to improve intake and digestibility of roughages (Getahun, 2001). In Afar region even though to get commercial concentrate is very difficult and expensive, fortunately enough Tendaho sugar factory has already started producing molasses which can be used as a supplement to Afar sheep breed. Moreover, sugar 
cane is being cultivated in the area by agro-pastoralist as a partner of out grower; this will result to high availability of molasses in the area that can be used as feed to livestock. However, how to feed molasses to the animals and how much they should be offered need a deep study. Therefore, the objective of this study is to determine how much molasses should be offered to animals without compromising weight loss and any health problems. The Afar sheep formerly referred to as Adal sheep in literature, is a fat-tailed sheep. This breed manifests a tail attribute somewhat intermediate between the true fat-tailed and fat-rumped types of sheep, which may be the result of interbreeding between those sheep populations. It is a small-sized breed with mature weight ranging 30-35 kilograms ( $\mathrm{kg}$ ) (Tesfaye et al., 2008). This breed is hardy and tolerates periods of drought relatively well as the breed evolved under harsh environmental conditions. The Afar sheep have small ears and usually have a dewlap and thick layers of fat on the brisket. The fat tail has a wide base and reaches below the hocks. Hair is short and coarse, the predominant color being solid blond with other colors ranging from shaded white to light brown. Molasses can reduce the dusty powdery nature of some finely ground feeds. In this role, it makes a feed mixture more palatable and edible to livestock. Molasses can be added to replace missing sugar and trace minerals and help with fermentation in cases of low quality forages especially with low sugar levels. Supplementing poor quality hay with molasses will increase feed intake and improve palatability. Microbes in the rumen break down the sugars in molasses rapidly, which extensively causes a rapid release of energy that makes molasses very useful for balancing other feeds in the dairy diet all year round. Therefore, this experiment was conducted with the objective to assess the comparative feeding value of molasses as energy sources, to promote molasses as energy feed sources for growing of Afar sheep and to assess the economic benefit of molasses as a source of feed for Afar sheep.

\section{Materials and Methods}

\subsection{Description of the experimental area}

The Experiment was conducted at Dubti Pastoral and Agro Pastoral Research Center (DPARC) (Figure 1). Which is located at $12 \mathrm{~km}$ from Samara, the capital city of the Afar National Regional State. The site is located between latitude $11^{\circ} 27^{\prime}$ North; longitude $41^{\circ} 20^{\prime}$ 'East and an altitude of 382 meter above sea level. The mean annual rainfall and temperature of the area is $400 \mathrm{~mm}$ and $34.1{ }^{\circ} \mathrm{C}$, respectively. Pastoral and agro-pastoral system of livestock production is the dominant agricultural activity of the community.

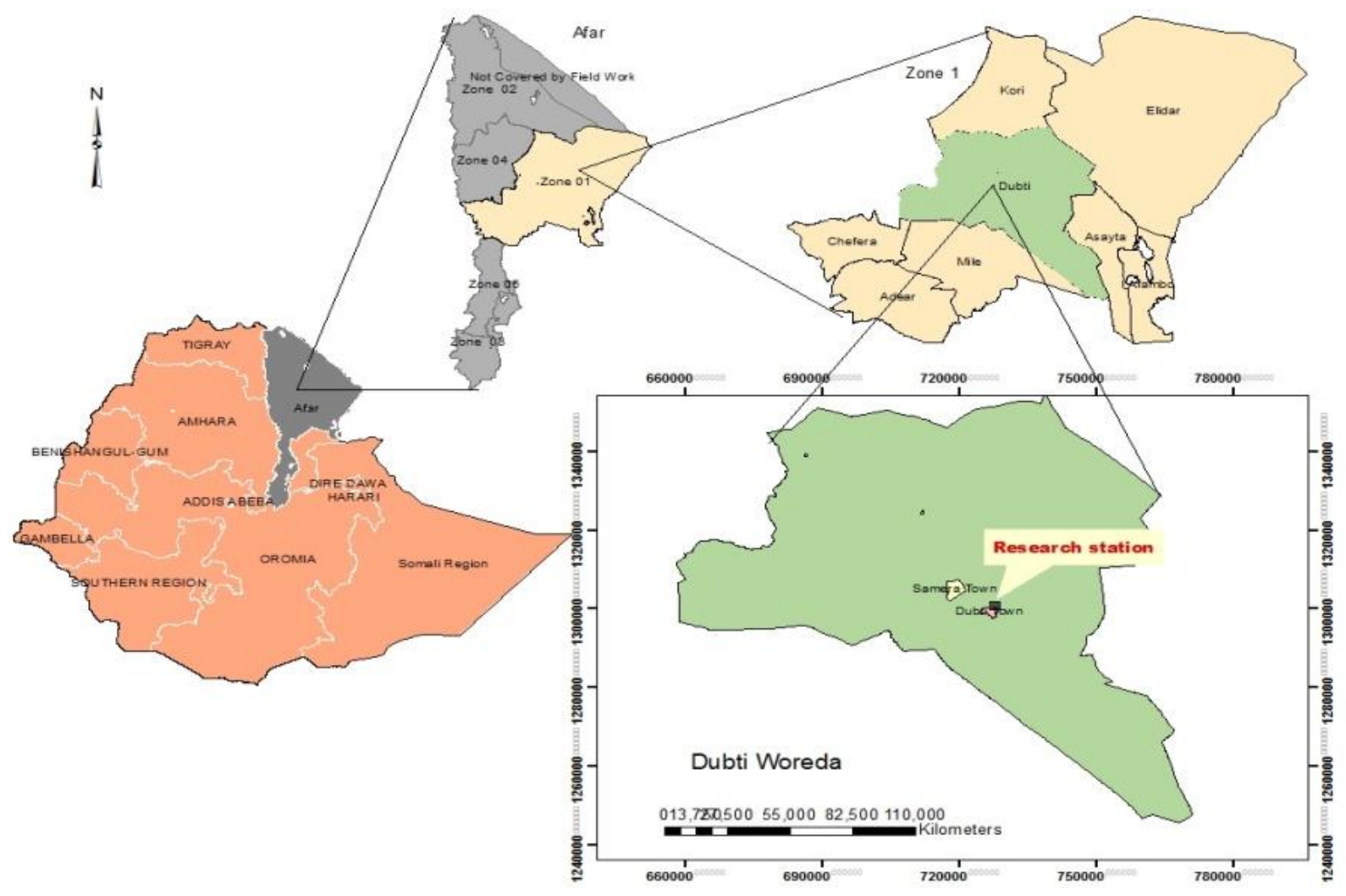

Figure 1. Dubti Pastoral and Agro Pastoral Research Center. 
2.2. Measurements and analyses

\subsubsection{Experimental animal and management}

Twenty-four yearling intact Afar sheep with average mean initial live weight of $16.25 \pm 1.25 \mathrm{~kg}$ (mean \pm SD) were used in the experiment. The sheep were housed in individual pens. All animals had free access to water and mineral salt block. Animals were quarantined for 3 weeks, and during this period, they were vaccinated to common disease in the area, dewormed and treated against external parasites. The animals were adapted to the experimental conditions and feeds for 15 days thereafter, which was followed by 90 days feeding trial and carcass evaluation conducted at the end of the experiment.

\subsubsection{Experimental design and treatments}

A randomized complete block design (RCBD) was used for the experiment. At the end of the quarantine period, animals were blocked into four blocks of six animals based on initial live weight, and animals within a block were randomly assigned to one of the four treatments. Treatments were mixed concentrate (wheat bran and Noug seed cake) $+20 \%$ inclusion molasses $\left(\mathrm{T}_{1}\right)$, mixed concentrate (wheat bran and Noug seed cake) $+15 \%$ inclusion molasses $\left(\mathrm{T}_{2}\right)$, mixed concentrate (wheat bran and Noug seed cake) $+10 \%$ inclusion molasses $\left(\mathrm{T}_{3}\right)$ and (wheat bran and Noug seed cake) $+0 \%$ inclusion of molasses $\left(\mathrm{T}_{4}\right)$. Supplements were offered twice a day at 8:00 and 16:00 $\mathrm{h}$ in two equal portions. The supplement was given at $300 \mathrm{~g} \mathrm{DM} / \mathrm{head} / \mathrm{day}$. Water and mineralized salt block were available free of choice. Hay and mixed concentrate refusals were collected, weighed, and discarded before the morning meal. Roughage will be made available to the animals ad libitum.

\subsubsection{Chemical analysis}

The samples of Wheat bran, Noug seed cake, Molasses and Panicum grass hay and refusals were analyzed for DM, OM, Ash, CP, NDF, ADF and ADL. Samples of feed offered and refusals were ground to pass $1 \mathrm{~mm}$ mesh screen size for determination of DM, ash and CP analyzed according to AOAC (1990). The DM, OM, CP and ash were determined according to AOAC (2005). CP content was measured by the Kjeldahl method as $\mathrm{N}^{*} 6.25$. The content of NDF, ADL and ADF was determined according to Van Soest and Robertson (1985).

\subsubsection{Feed intake and digestibility}

The amount of daily feed offers and refusals per head were recorded daily to determine daily feed intake. Grab samples feed were taken sometime in the middle of each week, and composite samples, one for each feed type, were formed for the entire feeding trial for chemical analysis. Daily feed intake of individual animal was calculated as following: Feed intake $(\mathrm{g})=$ Amount of feed offered $(\mathrm{g})$ - Amount of feed refused $(\mathrm{g})$. The metabolize energy (ME) intake of experimental animals were estimated from its digestible organic matter intake $(\mathrm{DOMI})$ by using the formula, ME $(\mathrm{MJ} / \mathrm{kg} \mathrm{DM})=\mathrm{DOMI} \times 0.0157$, Where, DOMI $=$ g digestible OM $/ \mathrm{kg} \mathrm{DM}$ (Solomon et al., 2004). The digestibility trial was conducted after 90 days of experimental feed. It was comprised of three-five days period for animals to adapt to carrying of the fecal collecting bags followed by a seven day feces collection period. Feces was collected and weighted every morning for each animal before giving of feed or water. The daily collected feces from each animal was weighed mixed thoroughly and $20 \%$ was sampled and kept in airtight plastic containers and stored at $-20{ }^{\circ} \mathrm{C}$ up to the completion of the digestibility trial. At the end of the digestibility trial the fecal sample was thawed, thoroughly mixed and sub samples were taken, weighed and partially dried at $60^{\circ} \mathrm{C}$ for 72 hours. The partially dried feces were ground to pass a $1 \mathrm{~mm}$ sieve, stored in plastic bags pending chemical analysis. Apparent digestibility percentage of DM, CP, Ash, $\mathrm{NDF}, \mathrm{ADF}$ and ADL was determined using the following formula (McDonald et al., 2002).

$$
\text { Nutrient digestibility }=\frac{\text { Nutrient intake }- \text { Nutrient excreted in feaces }}{\text { Nutrient intake }} * 100
$$

\subsubsection{Live weight gain}

Live weight of the animals was measured every 14 day afterwards, after overnight fasting. Average daily weight (BW) gain was calculated as the difference between the final and initial BW divided by the number of feeding days. Mean daily body weight change was calculated as;

$$
\operatorname{ADG}(\mathrm{kg} / \mathrm{d})=\frac{\text { Final body weight }(\mathrm{Kg})-\text { Initial live weight }(\mathrm{Kg})}{\text { No. of feeding days }}
$$

\subsubsection{Feed conversion efficiency}

Feed conversion efficiency is used to know how efficient the sheep are converting the feed into meat. It was measured using the formula suggested by Gülten et al. (2000). 
Feed conversion efficiency $=\frac{\text { Average daily live weight gain }(\mathrm{g})}{\text { Average daily feed intake }(\mathrm{g})}$

\subsubsection{Carcass parameters}

At the end of experiment, five experimental sheep from each treatment were slaughtered after overnight fasting. Weight of edible and non-edible non-carcass component yield were determined. Empty body weight and hot carcass weight of each animal were determined accordingly. Dressing percentage was calculated as proportion of hot carcass weight to slaughter and empty body weights.

$$
\text { Dressing percentage based on } \mathrm{SW}=\left(\frac{\text { Hot carcass weight }(\mathrm{Kg})}{\text { Slaughter weight }(\mathrm{Kg})}\right) \times 100
$$

\subsubsection{Partial budget analysis}

The partial budget analysis was taken to determine cost benefit (profitability) analysis supplementation of different proportions of concentrate mix, molasses and panicum antidotale grasses in feed of Afar sheep. The variable costs were calculated from supplementary feed and basal feed costs and medication which are supplied for each experimental sheep treatment costs. The partial budget analysis was calculated from the variable costs and benefits. At the end of the experiment, the selling price of each experimental sheep was estimated by three experienced local sheep dealers and the average of those three estimation price was taken. The variable costs were calculated from supplementary feed and basal feed costs which are supplied for each experimental sheep treatment costs. The total returns (TR) were determined by calculating the difference between the estimated selling prices and purchasing price of experimental sheep. Net return (NR) was calculated as;

$$
\mathrm{NR}=\mathrm{TR}-\mathrm{TVC}
$$

The change in net return $(\Delta \mathrm{NR})$ was calculated as the difference between change in total return $(\Delta \mathrm{TR})$ and the change in total variable costs $(\triangle \mathrm{TVC})$.

$$
\Delta \mathrm{NR}=\Delta \mathrm{TR}-\Delta \mathrm{TVC}
$$

\subsubsection{Statistical analysis}

Data were analyzed using analysis of variance (ANOVA) following the general linear model procedure of SAS (SAS 2002). Treatment means were separated by least significant difference (LSD) test. The model used for data analysis was; $Y i j=\mu+T i+B j+e i j$, where $Y i j=$ the response variable (the observation in jth block and ith treatment), $\mu=$ the overall mean, $T i=$ the treatment effect, $B j=$ the block effect and $e i j=$ the random error.

\section{Results and Discussion}

\subsection{Chemical composition of the treatment feeds}

The nutritional value of cane molasses in this study was found a high nitrogen source of feed in a feeding trail experiment of afar sheep. Nitrogen balance and the apparent intake of dry matter, organic matter in a mixed concentrate control diet was no apparent difference $(\mathrm{P}>0.05)$ at $10 \% 15 \%$ or $20 \%$ inclusion molasses dry matter on a mixed concentrate ration. While the digestibility of crude protein and nitrogen-free extract was $(\mathrm{P}<0.05)$ significantly increased by molasses, because it provides a certain amount of non-protein, non-sugars which have nutrient value can increased the crude protein content of the rations. There was a positive linear relationship between crude protein and digestible protein as a percentage of the dry matter. Although the apparent digestibility of dry matter, organic matter and gross energy was not affected by increasing level of molasses, the concentration of ammonia in the rumen was increased by high nitrogen intake. This result is in line with Karalazos and Swan (1977) reported no significant differences in digestibility when condensed molasses solution was included up to $20 \%$ on a DM basis in the diets of sheep. While the digestibility of nitrogen-free extract was depressed by the inclusion of molasses Chen et al. (1981). Supplementing poor quality hay with molasses will increase feed intake and improve palatability Because, microbes in the rumen break down the sugars in molasses rapidly, this extensively causes a rapid release of energy that makes molasses very useful for balancing other feeds in the sheep fattening. The chemical composition of the basal diet and the treatment feeds (Concentrate mix and molasses) is presented in Table 1. As indicated in the table the CP content of grass (panicum antidotale) hay, Concentrate mix and molasses was 95, 252, $38.4 \mathrm{~g} / \mathrm{kg} \mathrm{DM}$, respectively. In the table shown the $\mathrm{CP} g / \mathrm{kg}, \mathrm{DM} \mathrm{g} / \mathrm{kg}$, and $\mathrm{OM} \mathrm{g} / \mathrm{kg}$, content of the concentrate mix was found to be higher than all the feed materials used in the experiment. 
Table 1. Chemical composition of treatment feed ingredients.

\begin{tabular}{|c|c|c|c|}
\hline \multirow[t]{2}{*}{ Chemical Composition } & \multicolumn{3}{|c|}{ Feeds } \\
\hline & Hay & Molasses & Concentrate mix \\
\hline $\mathrm{DM}(\mathrm{g} / \mathrm{kg})$ & 916 & 724.5 & 938 \\
\hline $\mathrm{OM}$ (g/kg DM) & 901 & 812.14 & 921 \\
\hline $\mathrm{CP}(\mathrm{g} / \mathrm{kg} \mathrm{DM})$ & 95 & 38.42 & 252 \\
\hline NDF (g/kg DM) & 600 & - & 377 \\
\hline $\mathrm{ADF}(\mathrm{g} / \mathrm{kg} \mathrm{DM})$ & 402 & - & 205 \\
\hline $\operatorname{ADL}(\mathrm{g} / \mathrm{kg} \mathrm{DM})$ & 50 & - & 75 \\
\hline Hemicelluloses (g/kg DM) & 198 & - & 172 \\
\hline Cellulose (g/kg DM) & 352 & - & 130 \\
\hline
\end{tabular}

DM: dry matter; OM: organic matter; CP: crude protein; NDF: neutral detergent fiber; ADF: acid detergent fiber; ADL: acid detergent lignin;

\subsection{Feed intake}

The mean values of daily DM and nutrient intake of Afar sheep fed on supplementing different levels of molasses inclusion on concentrates mix with a basal diet of cultivated pasture (Panicum antidotale hay are presented in Table 2. Feed intake is a function of metabolic requirements and has been related to metabolic body weight (Van Soest, 1994). As the result shows, The dry matter intake (DMI), organic matter intake (OMI), digestible organic matter intake (DOMI), and total dry matter intake (TDMI), did not differ $(P>0.05)$ between treatments. While the $0 \%$ inclusion of molasses treatment tended to have the lowest intake. These results were in agreement with Karalazos and Swan (1977) and Chen et al. (1981) who also reported no significant differences in dry matter intake or organic matter intake when including condensed molasses solution at levels of up to $20 \%$ on a DM basis in concentrate diets fed to sheep. Similarly, Potter et al. (1985) who stated that no significant differences in dry matter intake when including sugarcane condensed molasses solution up to levels of $15 \%$ on a $\mathrm{DM}$ basis to replace corn and/or soybean in a diet fed to cattle. Significant $(\mathrm{P}<0.05)$ difference in NDF and ADF intake was observed among treatments. It was observed that the NDF and ADF intake was higher $(\mathrm{P}<0.05)$ for sheep in T2 and T1 than sheep in T3, and T4. The result shows that 439.7g/day, 258.9 g/day and $429.4 \mathrm{~g} /$ day, $242.8 \mathrm{~g} /$ day for T2 and T1 NDF and ADF respectively. The observed comparable NDF and ADF intake among the treatments may justify that, the inclusion of molasses at $15 \%$ and $20 \%$ in the diet could be a good supplement instead of conventional concentrates mixture (WB and NSC). In contrast to this trial, restricted inclusion of molasses in the diet increases Hay dry matter intake (HDMI), crude protein intake and crude fiber intake, the reason stated that, supplementing hay with molasses will increase feed intake and improve palatability, microbes in the rumen break down the sugars in molasses rapidly, which extensively causes a rapid release of energy. Dry matter intake as percentage of body weight in the present study was within the range 3.58-3.8\%. Total dry matter intake of sheep showed almost similar trend throughout the experimental period.

Table 2. Daily dry matters and nutrients intake of Afar sheep feed different level of molasses inclusion in the diet.

\begin{tabular}{llllll}
\hline Intake (g/d) & $\mathbf{2 0 \%}$ Molasses & $\mathbf{1 5 \%}$ Molasses & $\mathbf{1 0 \%}$ Molasses & 0\% Molasses & SEM \\
\hline Hay DM intake & $432.8^{\mathrm{a}}$ & $433.5^{\mathrm{a}}$ & $428.6^{\mathrm{a}}$ & $421.06^{\mathrm{a}}$ & 1.31 \\
Supp. DM intake & $354.12^{\mathrm{a}}$ & $353.11^{\mathrm{a}}$ & $351.25^{\mathrm{a}}$ & $349.5^{\mathrm{a}}$ & 0.19 \\
Tot. DM intake & $786.92^{\mathrm{a}}$ & $784.61^{\mathrm{a}}$ & $779.85^{\mathrm{a}}$ & $770.56^{\mathrm{a}}$ & 1.32 \\
Tot. DM intake (\% BW) & $3.58^{\mathrm{a}}$ & $3.79^{\mathrm{a}}$ & $3.49^{\mathrm{a}}$ & $3.8^{\mathrm{a}}$ & 0.95 \\
DOMI & 36 & 37 & 35 & 38 & 1.33 \\
OM intake & $715.2^{\mathrm{ab}}$ & $721.7^{\mathrm{ab}}$ & $701.3^{\mathrm{ab}}$ & $712.3^{\mathrm{ab}}$ & 1.47 \\
CP intake & $185.2^{\mathrm{a}}$ & $187.2^{\mathrm{a}}$ & $182.2^{\mathrm{a}}$ & $181.1^{\mathrm{a}}$ & 1.21 \\
NDF intake & $429.4^{\mathrm{b}}$ & $439.7^{\mathrm{ab}}$ & $394.3^{\mathrm{a}}$ & $381.1^{\mathrm{a}}$ & 0.98 \\
ADF intake & $242.8^{\mathrm{ab}}$ & $258.9^{\mathrm{ab}}$ & $226.3^{\mathrm{a}}$ & $223.6^{\mathrm{a}}$ & 0.99 \\
Nutrient intake during digestibility trial & $797.5^{\mathrm{a}}$ & $798.4^{\mathrm{a}}$ & $796.9^{\mathrm{a}}$ & $795.1^{\mathrm{a}}$ & 1.24 \\
g/d) DM in take & & & & & \\
OM in take & $706.2^{\mathrm{b}}$ & $715.3^{\mathrm{b}}$ & $690.7^{\mathrm{b}}$ & $701.6^{\mathrm{b}}$ & 1.93 \\
CP intake & $176.7^{\mathrm{c}}$ & $188.6^{\mathrm{c}}$ & $173.6^{\mathrm{c}}$ & $182.9^{\mathrm{c}}$ & 1.37 \\
NDF intake & $453.8^{\mathrm{b}}$ & $463.6^{\mathrm{c}}$ & $415.4^{\mathrm{a}}$ & $404.9^{\mathrm{a}}$ & 0.89 \\
ADF intake & $243.6^{\mathrm{c}}$ & $263.5^{\mathrm{c}}$ & $219.8^{\mathrm{b}}$ & $210.1^{\mathrm{b}}$ & 0.87 \\
\hline
\end{tabular}

${ }^{a, b, c}$ Means within the same within a row not bearing a common superscript differ significantly $(\mathrm{p}<0.05)$; SEM: standard error mean; DM: dry matter; OM: organic matter; CP: crude protein; DOMI: digestible organic matter intake, NDF: neutral detergent fiber; ADF: acid detergent fiber; 


\subsection{Dry matter and nutrients digestibility}

The apparent DM and nutrients digestibility percentages of experimental feeds are shown in Table 3 . The result showed that significant difference were observed in apparent DM, NDF and ADF digestibility among treatments $(\mathrm{P}<0.05)$. The $15 \%$ inclusion of molasses treatment had a higher $(P<0.05)$ DM digestibility than the $20 \%$ inclusion of molasses treatment. The apparent OM digestibility of the $0 \%$ inclusion of molasses and $10 \%$ inclusion of molasses treatments differed $(P<0.05)$ from the $15 \%$ and $20 \%$ inclusion of molasses treatment, with the $15 \%$ inclusion of molasses treatment having a higher $(P<0.05)$ OM digestibility than the $0 \%$ inclusion of molasses and $10 \%$ inclusion of molasses treatments. Similarly the $15 \%$ and $20 \%$ inclusion of molasses treatment had a higher $(P<0.05) \mathrm{NDF}$ and ADF digestibility than the $10 \%$ and $0 \%$ inclusion of molasses treatments accordingly. The $0 \%$ inclusion of molasses and $10 \%$ inclusion of molasses diets have a higher NDF and ADF content. This could be a possible reason for the lower $(\mathrm{P}<0.05)$ DM digestibility for the $10 \%$ inclusion of molasses and the lower $(\mathrm{P}<0.05) \mathrm{OM}$ digestibility for the $0 \%$ inclusion of molasses and $10 \%$ inclusion of molasses treatments.

Table 3. DM and nutrients digestibility percentages of experimental feeds.

\begin{tabular}{llllll}
\hline Parameters & \multicolumn{5}{c}{ Treatments } \\
\cline { 2 - 6 } & $\mathbf{2 0 \%}(\mathbf{T 1})$ & $\mathbf{1 5 \%}(\mathbf{T 2})$ & $\mathbf{1 0 \%}(\mathbf{T 3})$ & $\mathbf{0 \%}(\mathbf{T 4})$ & SEM \\
\hline DM digestibility & $72.0^{\mathrm{b}}$ & $76.1^{\mathrm{b}}$ & $68.4^{\mathrm{b}}$ & $65.7^{\mathrm{b}}$ & 1.8 \\
OM digestibility & $72.8^{\mathrm{b}}$ & $76.3^{\mathrm{b}}$ & $69.0^{\mathrm{a}}$ & $67.6^{\mathrm{a}}$ & 1.1 \\
CP digestibility & $71.4^{\mathrm{c}}$ & $71.9^{\mathrm{c}}$ & $69.7^{\mathrm{b}}$ & $69.4^{\mathrm{b}}$ & 2.1 \\
NDF digestibility & $69.6^{\mathrm{ab}}$ & $75.0^{\mathrm{b}}$ & $65.8^{\mathrm{b}}$ & $62.1^{\mathrm{b}}$ & 0.8 \\
ADF digestibility & $68.1^{\mathrm{b}}$ & $76.1^{\mathrm{ab}}$ & $65.1^{\mathrm{a}}$ & $63.6^{\mathrm{a}}$ & 0.9 \\
\hline
\end{tabular}

${ }^{a, b, c}$ Means within a row with different superscript differ significantly $(\mathrm{P}<0.05)$

\subsection{Live weight gain}

Mean initial and final live weight, average daily gain (ADG) weight changes and feed conversion ratio (FCR) of the experimental sheep on the different treatment feeds are presented in Table 4. Initial body weight which has a direct effect on the final weights, as the result shows that, all the four treatments of the initial body weights are similar among the treatments. Final body weight, average daily gain and weight changes shows significant difference in (T2) 15\% molasses inclusion (P<0.05) followed by (T1) $20 \%$ molasses inclusion. This maybe as a result of the optimum quantity balanced ration with restricted inclusion of molasses fed were positively influenced the experimental treatments. The average daily gain for this trial was $62.2 \mathrm{~g} /$ day; which is lower than Sheridan et al. (2003) in South Africa $0.281 \mathrm{~kg} / \mathrm{lamb} / \mathrm{day}$. Similarly in South Africa, Gouws et al. (2016) reported a maximum ADG of $0.302 \mathrm{~kg} / \mathrm{lamb} /$ day and a minimum ADG of $0.289 \mathrm{~kg} / \mathrm{lamb} /$ day when lambs were fed a feedlot diet. There were differences $(\mathrm{P}<0.05)$ in body weight gained and average daily gains between the $15 \%$ molasses inclusion of treatment and the $0 \%$ molasses inclusion of treatment, with the $0 \%$ molasses inclusion of treatment having a lower $(\mathrm{P}<0.05)$ bodyweight gain and average daily gain compared to the $15 \%$ molasses inclusion of treatment. Body weight gained and average daily gains of the $0 \%$ molasses inclusion of treatment did not differ $(\mathrm{P}>0.05)$ from the $10 \%$ molasses inclusion of treatment. The body weight gained and average daily gains of the $15 \%$ molasses inclusion of treatment is higher $(\mathrm{P}<0.05)$ from the $0 \%$ molasses inclusion of treatment, $10 \%$ molasses inclusion of treatment and $20 \%$ molasses inclusion of treatment. The reason may be the more inclusion of molasses in diet there is an increase of competition for substrate of microbes in the rumen resulted in loss of feed. Based on the result, the restricted inclusion of molasses in the feed has a positive impact for body weight gain of sheep and could be used as energy source. The differences in daily BW gain and ADG between treatments in the present study might be the differences in daily DM, and CP intake as well as DM and CP digestibility between treatment groups. 
Table 4. Body weight gain of Afar sheep feed different level of molasses inclusion on the diet of sheep feeds.

\begin{tabular}{llllll}
\hline BW parameters & $\mathbf{2 0 \%}$ Molasses & $\mathbf{1 5 \%}$ Molasses & $\mathbf{1 0 \%}$ Molasses & $\mathbf{0 \%}$ Molasses & SEM \\
\hline Body weight (kg) & & & & \\
Initial & $15.53^{\mathrm{A}}$ & $15.52^{\mathrm{A}}$ & $15.54^{\mathrm{A}}$ & $15.41^{\mathrm{A}}$ & 0.034 \\
Final & $27.84^{\mathrm{B}}$ & $29.35^{\mathrm{A}}$ & $26.79^{\mathrm{AB}}$ & $25.67^{\mathrm{AB}}$ & 0.013 \\
ADG (g/kg) & $63.15^{\mathrm{AB}}$ & $69.59^{\mathrm{A}}$ & $63.45^{\mathrm{AB}}$ & $60.80^{\mathrm{B}}$ & 0.011 \\
Weight gain (kg) & $12.31^{\mathrm{B}}$ & $13.83^{\mathrm{A}}$ & $11.25^{\mathrm{AB}}$ & $10.26^{\mathrm{AB}}$ & 0.011 \\
FCR (g DMI/g ADG) & $13.12^{\mathrm{A}}$ & $12.15^{\mathrm{C}}$ & $13.44^{\mathrm{B}}$ & $13.94^{\mathrm{B}}$ & 0.014 \\
\hline
\end{tabular}

A, B, C means within the same row not bearing a common superscript differ significantly $(\mathrm{P}<0.05)$; ADG: average daily weight gain; BW: body weight; DMI: dry matter intake; FCR: feed conversion ratio; SEM: standard error mean.
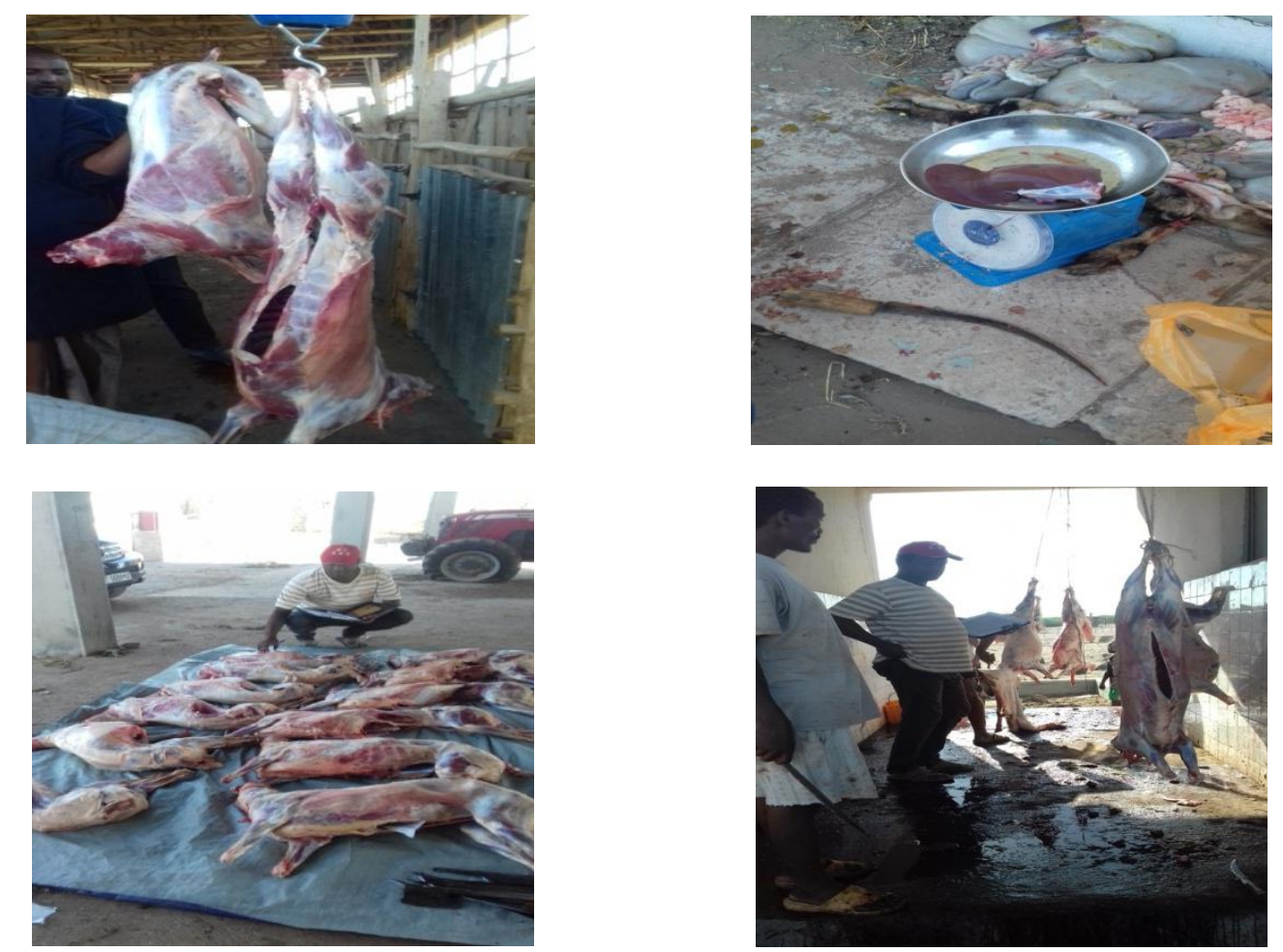

Figure 2. During carcass measurement at Dubti.
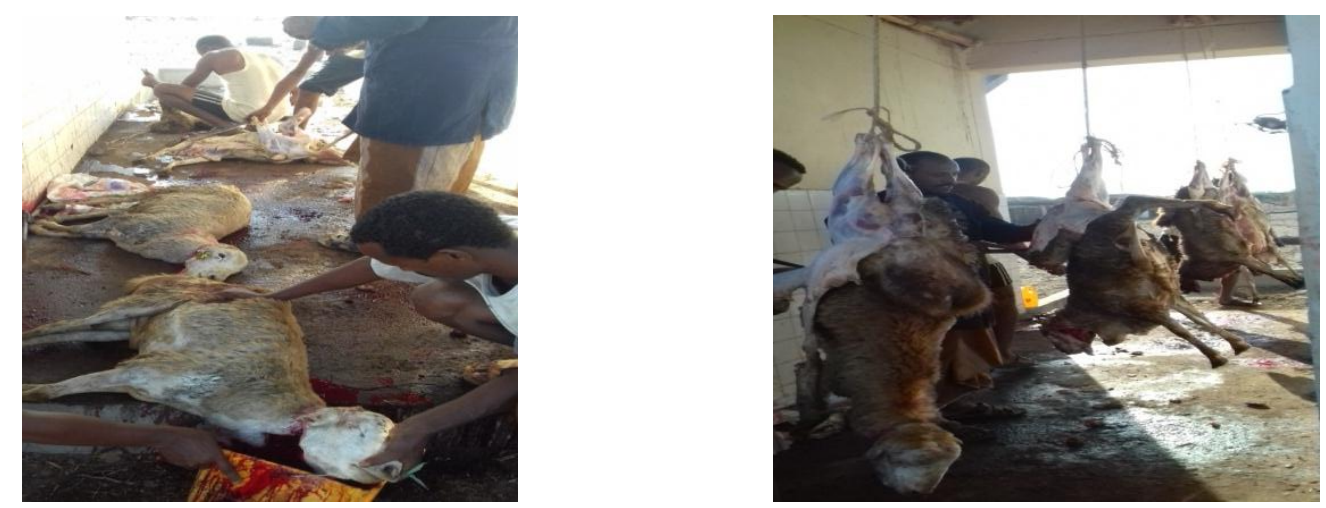

Figure 3. During slaughtering at Dubti livestock barn. 


\subsection{Feed efficiency}

The feed conversion ratio is calculated the amount of feed $(\mathrm{kg})$ required for an animal to gain a kilogram of body weight (Beauchemin et al., 1997). The feed conversion ratio in this trial was 13.12 (T1), 12.15 (T2), 13.44 (T3) and 13.94 (T4) respectively. Hence, based on the result it is expected that the animals with a higher average daily gain, but consuming the same/similar amounts of feed will have an improved FCR. This could have been the situation in this study leading to differences between the feed conversion ratios. There were no differences $(\mathrm{P}>0.05)$ in the feed intake of dry matter; however average daily gains did differ, thus leading to differences in FCR. There were no differences $(P>0.05)$ in dry matter feed intake between among all treatments, but the $0 \%$ inclusion of molasses treatment had a lower ( $\mathrm{P}<0.05)$ ADG than the $10 \%, 15 \%$ and $20 \%$ inclusion of molasses treatment. Thus, the $0 \%$ inclusion of molasses treatment resulted in an expected higher $(\mathrm{P}<0.05) \mathrm{FCR}$ than the rest of all treatments. The probable reason for the differing of the feed conversion ratios between the treatments in this trial were due to the differences in average daily gains among the treatment animals.

\subsection{Carcass and non-carcass characteristics}

Different level of molasses inclusion effects on carcass characteristics of Afar sheep are presented in Table 5 and Figure 2 and 3. The result shows that, slaughter body weight and hot carcass weight significant difference $(\mathrm{P}<0.05)$ was observed among treatments. Slaughter body weight and hot carcass weight of the $0 \%$ inclusion of molasses treatment was lower $(\mathrm{P}<0.05)$ than $10 \%, 15 \%$ and $20 \%$ inclusion of molasses treatment. The reason for this could possibly be due to the differences $(\mathrm{P}<0.05)$ in the final live body weights. Cloete et al. (2004) reported that a higher final live body weight will directly result in a higher carcass weight. The $15 \%$ inclusion of molasses treatment had a tendency to have the highest final live body weight and also showed a tendency to have the highest slaughter body weight and hot carcass weight; whereas the $0 \%$ inclusion of molasses treatment had a tendency to have the lowest weights. Dressing percentage is the proportion of final live body weight that is converted into carcass (Warmington and Kirton, 1990). In this study dressing percentage was calculated using hot carcass weight as a proportion of the final live body weight. The dressing percentage of this trial for (T1) $47.1 \%$, (T2) $49.1 \%$, (T3) $46.2 \%$ and (T4) was $44 \%$. As the result indicated that, the dressing percentage of the $0 \%$ inclusion of molasses treatment differed $(\mathrm{P}<0.05)$ from the $15 \%$ inclusion of molasses treatment, with $0 \%$ inclusion of molasses treatment showing the lowest dressing percentage. It was also noted that the dressing percentage of the $15 \%$ inclusion of molasses treatment was highest $(\mathrm{P}<0.05)$ than among all treatment. However, there is no difference $(\mathrm{P}>0.05)$ between the $10 \%$ and $20 \%$ inclusion of molasses treatment. These differences in the dressing percentage could have been as a result of the differences in final live body weights of the lambs. For example, the $0 \%$ inclusion of molasses treatment had a tendency for the lowest final live body weight and had the lowest $(\mathrm{P}<0.05)$ dressing percentage. An increase in slaughter weight is usually as a result of an increased fat percentage (Webb and Casey, 1995).

Table 5. Effects of different level of molasses inclusion on carcass characteristics of Afar sheep.

\begin{tabular}{lllllc}
\hline Item & $\mathbf{2 0 \%}$ Molasses & $\mathbf{1 5 \%}$ Molasses & $\mathbf{1 0 \%}$ Molasses & 0\% Molasses & SEM \\
\hline Slaughter body weight $(\mathrm{kg})$ & $27.84^{\mathrm{B}}$ & $29.35^{\mathrm{A}}$ & $26.79^{\mathrm{AB}}$ & $25.67^{\mathrm{AB}}$ & 0.034 \\
Empty body weight $(\mathrm{kg})$ & $22.53^{\mathrm{B}}$ & $24.93^{\mathrm{A}}$ & $22.33^{\mathrm{AB}}$ & $22.11^{\mathrm{AB}}$ & 0.22 \\
Hot carcass weight $\mathrm{Kg}$ & $13.28^{\mathrm{B}}$ & $14.41^{\mathrm{A}}$ & $12.39^{\mathrm{AB}}$ & $11.27^{\mathrm{AB}}$ & 0.10 \\
Dressing percentage & $47.1^{\mathrm{B}}$ & $49.1^{\mathrm{A}}$ & $46.2^{\mathrm{B}}$ & $44.0^{\mathrm{C}}$ & 0.34 \\
\% empty body weight & $57.97^{\mathrm{A}}$ & $59.23^{\mathrm{B}}$ & $57.46^{\mathrm{A}}$ & $56.29^{\mathrm{AB}}$ & 0.51 \\
\hline
\end{tabular}

A, B, C, means with different superscripts in row are significantly different $(\mathrm{P}<0.05)$ SEM: standard error mean.

\subsection{Edible and non-edible offal's}

The edible and non-edible of non-carcass component of Afar sheep fed different level molasses inclusion with concentrates mix presented in Table 6 . In this study, the ratio of lean meat: fat, lean meat: bone and lean meat + fat: bones were significant different $(\mathrm{P}<0.05)$ among experimental treatments. Additionally, edible and nonedible offal of carcass parameters like head, liver, heart, kidney, spleen, testicles, skin, gut-fill and gut empty were not apparently different $(\mathrm{P}>0.05)$ affected by different level of molasses inclusion in concentrate mix among treatments. The ratio of lean meat of the $0 \%$ molasses inclusion treatment differed $(\mathrm{P}<0.05)$ from the $10 \% 15 \%$ and $20 \%$ molasses inclusion treatment. The $0 \%$ molasses inclusion treatment had a lower $(\mathrm{P}<0.05)$ lean meat: fat ratio than the $10 \%, 15 \%$ and $20 \%$ molasses inclusion treatment. This could be as a result of the dressing percentage of the $0 \%$ molasses inclusion treatment being significantly lower than the other treatments. Brand et al. (2017) reported that lambs with fatter carcasses have higher dressing percentages. Therefore a 
carcass containing less fat will result in a lower dressing percentage. Since the $0 \%$ molasses inclusion treatment had a lower $(\mathrm{P}<0.05)$ dressing percentage than the $10 \%, 15 \%$ and $20 \%$ molasses inclusion treatment, it is suggested that those sheep would also have a lower $(\mathrm{P}<0.05)$ lean meat: fat ratio in the different carcass parameters. In this stud, (T2) $15 \%$ inclusions of molasses treatments had significantly higher $(\mathrm{P}<0.05)$ lean meat: fat ratio weight than other treatments. The result of current study showed that except lean meat: fat ratio, a total edible offal's component and none edible products were not apparently different $(\mathrm{P}>0.05)$ among treatments.

Table 6. Effects of different level of molasses levels inclusion on non-carcass components of Afar sheep.

\begin{tabular}{|c|c|c|c|c|c|}
\hline Item & 20\% Molasses & 15\% Molasses & 10\% Molasses & 0\% Molasses & SEM \\
\hline Head (kg) & $1.24^{\mathrm{A}}$ & $1.31^{\mathrm{A}}$ & $1.34^{\mathrm{A}}$ & $1.33^{\mathrm{A}}$ & 0.16 \\
\hline Liver(g) & $281.19^{\mathrm{A}}$ & $287.21^{\mathrm{A}}$ & $282.51^{\mathrm{A}}$ & $282.13^{\mathrm{A}}$ & 3.14 \\
\hline Heart(g) & $76.81^{\mathrm{A}}$ & $77.63^{\mathrm{A}}$ & $75.31^{\mathrm{A}}$ & $74.30^{\mathrm{A}}$ & 1.19 \\
\hline Kidney(g) & $133.58^{\mathrm{A}}$ & $134.02^{\mathrm{A}}$ & $133.27^{\mathrm{A}}$ & $132.48^{\mathrm{A}}$ & 1.09 \\
\hline Spleen $(\mathrm{g})$ & $29.33^{\mathrm{A}}$ & $28.46^{\mathrm{A}}$ & $28.68^{\mathrm{A}}$ & 26. $.45^{\mathrm{A}}$ & 0.17 \\
\hline Testicles $(\mathrm{g})$ & $201.11^{\mathrm{A}}$ & $203.13^{\mathrm{A}}$ & $203.28^{\mathrm{A}}$ & $204.31^{\mathrm{A}}$ & 1.81 \\
\hline $\operatorname{Skin}(g)$ & $3.10^{\mathrm{A}}$ & $3.19^{\mathrm{A}}$ & $3.23^{\mathrm{A}}$ & $3.24^{\mathrm{A}}$ & 0.16 \\
\hline Gut fill $(\mathrm{kg})$ & $3.91^{\mathrm{A}}$ & $3.88^{\mathrm{A}}$ & $3.93^{\mathrm{A}}$ & $3.96^{\mathrm{A}}$ & 0.16 \\
\hline Gut empty(kg) & $1.11^{\mathrm{A}}$ & $1.17^{\mathrm{A}}$ & $1.09^{\mathrm{A}}$ & $1.14^{\mathrm{A}}$ & 0.15 \\
\hline Gut content $(\mathrm{kg})$ & $2.99^{\mathrm{A}}$ & $2.97^{\mathrm{A}}$ & $2.86^{\mathrm{A}}$ & $2.96^{\mathrm{A}}$ & 0.17 \\
\hline Kidney fat $(\mathrm{g})$ & $13.7^{\mathrm{B}}$ & $15.6^{\mathrm{A}}$ & $13.6^{\mathrm{B}}$ & $11.8^{\mathrm{AB}}$ & 0.13 \\
\hline Abdominal fat $(\mathrm{g})$ & $69.7^{\mathrm{C}}$ & $78.3^{\mathrm{A}}$ & $69.5^{\mathrm{C}}$ & $58.9^{\mathrm{B}}$ & 0.01 \\
\hline Stomach fat $(\mathrm{g})$ & $198.1^{\mathrm{C}}$ & $217.4^{\mathrm{A}}$ & $197.8^{\mathrm{C}}$ & $187.7^{\mathrm{B}}$ & 0.01 \\
\hline Genitals fat $(\mathrm{g})$ & $13.1^{\mathrm{B}}$ & $14.9^{\mathrm{A}}$ & $13.0^{\mathrm{B}}$ & $11.6^{\mathrm{AB}}$ & 0.11 \\
\hline
\end{tabular}

A, B, C Means with different superscripts in rows are significantly different $=(\mathrm{P}<0.01)$

\subsection{Partial budget analysis}

In computing the partial budget analysis includes all variable costs, change in net income and change in net profit. In this study feed, medication and animal cost were considered as variable costs whereas the sale of sheep also used as an income source. The partial budget analysis of Afar sheep fed on different level of molasses inclusion in the diet with concentrates mix presented Table 7. The partial budget analysis was made to evaluate the economic advantages of different level of molasses inclusions in the diet. The result of this study indicated that higher net income (1098 ETB/sheep) was obtained from the sheep supplemented with (T2) 15\% inclusions of molasses treatments; followed by T1(20\%), T3 (10\%), T4 (0\%), in decreasing order respectively. This result indicated that there was no loss of Birr/sheep in all treatments. Based on this study the net profit income, T2 $(15 \%)$ inclusions of molasses treatments counterweights other treatments and is endorsed as best. However, all different level of inclusion of molasses used in this study persuaded positive net profit and income and thus can be engaged in feeding provisions depending on the availability of feeds and cost feasibility.

Table 7. Partial budget analysis of Afar sheep fed on different level of molasses inclusion in the diet.

\begin{tabular}{|c|c|c|c|c|}
\hline \multirow[t]{2}{*}{ Parameters } & \multicolumn{4}{|c|}{ Treatments } \\
\hline & T1 $(20 \%)$ & T2 $(15 \%)$ & T3 $(10 \%)$ & $4(0 \%)$ \\
\hline Purchase price of sheep (ETB/head) & 686 & 686 & 686 & 686 \\
\hline Panicum hay consumed (kg/head) & 28.3 & 29.7 & 28.2 & 27.1 \\
\hline Cane molasses consumed (kg/head) & 60 & 45 & 30 & - \\
\hline Wheat bran consumed (kg/head) & 16.9 & 17.2 & 16.4 & 16.1 \\
\hline Noug seed cake consumed (kg/head) & 13.1 & 13.8 & 13.6 & 12.9 \\
\hline Total supplement consumed (kg/head) & 29.6 & 30.2 & 29.1 & 28.2 \\
\hline Total feed consumed (kg/head) & 58.9 & 59.6 & 58.7 & 56.3 \\
\hline Cost of Panicum grass hay(ETB/head) & 158.3 & 159.1 & 157.8 & 159.2 \\
\hline Cost for molasses (ETB/head) & 42 & 31.5 & 21 & - \\
\hline Cost of Wheat bran (ETB/head) & 79.20 & 79.90 & 78.7 & 78.6 \\
\hline Cost of Noug seed cake (ETB/head) & 69.40 & 68.30 & 68.80 & 68.20 \\
\hline Cost of medication (ETB/head) & 22 & 13 & 21 & 16 \\
\hline Total variable cost (ETB/head) (TVC) & 1056.9 & 1037.8 & 1033.3 & 1008 \\
\hline Gross income $(\mathrm{R})(\mathrm{ETB} / \mathrm{head})$ & 1780 & 1920 & 1625 & 1510 \\
\hline Change in net income (ETB/head) & 1098 & 1234 & 939 & 824 \\
\hline
\end{tabular}




\section{Conclusions and Recommendations}

Based on the result of this study, concluded that in the diet with $15 \%$ molasses limit obtained the best result in nutrient immersion, weight gain and Nitrogen balance. Since if it exceeds at higher levels, its feeding value could be expected to decline by almost 50 percent. Moreover, when it exceeded up to $20 \%$ there will be an increase of competition for substrate of microbes in the rumen resulted in loss of feed. So sheep can be fed molasses in the diets which should be included up to $15 \%$ as of optimum level that can be help the animas (sheep) without adverse effect and a remarkable change in nutrient immersion and nitrogen balance. On top of that, molasses has to be given in a restricted amount at 15\% inclusion which improves feed intake of fibers, weight gain; nitrogen balance and it enhance mechanical digestion of fiber. Moreover, Feeding molasses to sheep will improve help to maintain body condition and appetite and result in less feed waste. Therefore benefits of feeding molasses in our studies, there is no doubt that molasses is an excellent source of energy and minerals for small ruminants (sheep). It can be fed in various ways and is very useful for small ruminant (sheep) producers and could feel confident feeding molasses, a safe and economical supplement and it has an advantage of high digestible energy, high level of degradable protein, highly palatable, ideal to complement low protein.

\section{Conflict of interest}

None to declare.

\section{References}

AOAC, 1990. Official methods of analysis of the Association of Official Analytical Chemists. 2 vols. 15th ed. Washington, DC, USA.

AOAC, 2005. Official Methods of Analysis. Association of Official Analytical Chemists. 18th edn. Arlington, VA, USA.

Beauchemin KA, SDM Jones, LM Rode and VJH Sewalt, 1997. Effects of fibrolytic enzymes in corn or barley diets on performance and carcass characteristics of feedlot cattle. Can. J. Anim. Sci., 77: 645-653.

Brand TS, EJ VanderWesthuizen, DA VanderMerwe and LC Hoffman, 2017. Effects of days in Feed lot on growth performance and carcass characteristics of Merino, South African Mutton Merino and Dorper lambs. S. Afr. J. Anim. Sci., 47: 26-33.

Chen MC, CB Ammerman, PR Henry, AZ Palmer and SK Long, 1981. Citrus condensed molasses solubles as an energy source for ruminants. J. Anim. Sci., 53: 253-259.

Cloete SWP, LC Hoffman and JE Fourie, 2004. A comparison between the body composition, carcass characteristics and retail cuts of South African Mutton Merino and Dormer sheep. S. Afr. J. Anim. Sci., 34: 44-51.

FAO (Food and Agriculture Organization of the United Nations), 2004. FAOSTAT data (http://faostat.fao.org/faostat/collections?subset=agriculture, Retrieved on 9-December-2008).

Getachew A, 2005. Evaluation of forage yield and effects of forms of feeding of Acacia saligna on intake and live weight gain of Farta sheep fed on Grass hay. Msc Thesis, Haramaya University, Haramaya, Ethiopia.

Getahun L, 2001. Growth pattern and carcass characteristic of Somali and Mid- Rift Valley Goats. MSc Thesis, Alemaya University, Alemaya, Ethiopia. pp. 123.

Gouws RF, FM Hagg, RH VanderVeen, LJ Erasmus and DE Holm, 2016. The potential of Calcified marine algae and/or Capsicum as natural alternatives to Monensin in lamb feedlot diets. ADSA, Joint annual meeting, 19-23 July, Salt Lake City, Utah, USA.

Gülten K, F Rad and M Kindir, 2000. Growth performance and feed conversion efficiency of Siberian Sturgeon juveniles (Acipenser baeri) reared in concentrate ways. Turkey J. Vet. Anim. Sci., 24: 435-442.

Karalazos A and H Swan, 1977. The nutritional value for sheep of molasses and condensed molasses solubles. Anim. Feed Sci. Technol., 2: 143-152.

McDonald P, RA Edwards, JFD Greenhalgh and CA Morgan, 2002. Animal Nutrition $6^{\text {th }}$ Edition. Pearson Educational Limited. Edinburgh, Great Britain. pp. 255-657.

Potter SG, A Moya, PR Henry, AZ Palmer, HN Becker and CB Ammerman, 1985. Sugarcane condensed molasses solubles as a feed ingredient for finishing cattle. J. Anim. Sci., 60: 839-846.

Sheridan R, AV Ferreira and LC Hoffman, 2003. Production efficiency of South African Mutton Merino lambs and Boer goat kids receiving either a low or a high energy feedlot diet. Small Rumin. Res., 50: 75-82.

Solomon M, KJ Peters and T Azage, 2004. Effects of supplementation with foliages of selected multipurpose trees, their mixtures or wheat bran on feed intake, plasma enzyme activities, live weight and scrotal circumference gains in Menz Sheep. J. Livest. Pro. Sci., 89:253-264. 
Tesfaye K, L Tesfaye, D Hunduma, G Mieso and S Amsalu, 2008. Growth performance and carcass characteristics of Arsi-Bale goats castrated at different ages. J. Cell Anim. Biol., 2: 187-194.

Van Soest PJ and JB Robertson, 1985. Analysis of forages and fibrous foods. Ithaca: Cornell University, pp. 190-202.

Van Soest PJ, 1994. Nutritional ecology of the ruminant. 2nd Edition, Cornell University Press, Ithaca, USA. pp. 465-476.

Warmington BG and AH Kirton, 1990. Genetic and non-genetic influences on growth and carcass traits of goats. Small Rumin. Res., 3:147-165.

Webb EC and NH Casey, 1995. Genetic differences in fatty acid composition of subcutaneous adipose tissue in Dorper and SA Mutton Merino wethers at different live weights. Small Rumin. Res., 18: 81-88. 